\title{
1. Geofinance/banking between political and financial geographies
}

\section{Christian Sellar, Silvia Grandi and Juvaria Jafri}

\section{FINANCIAL GEOGRAPHIES}

This chapter proposes the notion of geofinance/banking to engage in and advance debates in both financial and political geography. Therefore, this section of the chapter summarizes key concepts in financial geography; the second section makes the case for looking at finance from a political geographical standpoint; the third expands on the notion of geofinance/ banking; and the fourth and fifth sections discuss broader implications of this as a model to understand finance in the semi-peripheries.

A rapidly developing field, financial geography is establishing itself as a multi-scalar and multidisciplinary area of study, with at least three recognizable foci (FinGeo 2018), which emerge habitually - but not exclusively - from the core of the financial system: (1) a sectoral focus which encompasses corporate finance, financial markets and intermediaries, personal finance, and government and regulation; (2) a cross-sectoral focus which emphasizes multidisciplinary research, such as on real estate, the geographies of financial flows, financial centers and networks, and financial technology (fintech); and (3) a development focus, which interrogates financial equality and its relationship with social justice, crises and responsible investment.

Sectoral studies, which are given to geographical contexts, reveal the crucial role of advanced business services - particularly core-based transnational consulting and accounting firms - in constituting and sustaining the legitimacy of a financialized economy (Dörry 2018). Thus, a missing critical mass of advanced financial services is a marker of a semi-peripheral financial area. Moreover, a sectoral focus highlights how conflict between established actors and emerging frontier financial systems, which are connected to the major financial centers, reshapes both the spatialities and the organization of the industry (Dixon and Monk 2014; Grandi 2018; Grandi and Parenti 2019; Parenti and Rosati 2018). Even though the basic power structure of finance, centered on New York and London, remains 
overwhelmingly intact (Cassis and Wójcik 2018; Wójcik 2013), such conflicts and re-organization are increasingly relevant, as the financialized economy swells at the expense of national models of stakeholder capitalism (Clark and Wójcik 2007).

The cross-sectoral focus captures, for instance, the notion that housing is 'a central carrier of practices of financialization' and that it 'bridges the balance sheet of households (debt and equity) with financial institutions' (Fernandez 2017, p. 1; see also Byrne and Norris 2017). Another example of a cross-sectoral focus is how discussions of fintech highlight how the 'organizational models coming out of Silicon Valley', such as 'Big Data' mining, digital money, distributed ledger technology, robo-advice and other forms of integration of information technology and finance, are being adopted by traditional financial firms, notwithstanding their size, legacies and sunken costs (Bassens et al. 2017).

Discussions on development include patterns of growth for financial service firms in the UK after the global financial crisis of 2007-09 and the ongoing process of leaving the European Union, showing that firms networked with other financial hubs grow faster, generating negative spillovers and divergent growth patterns within the local financial cluster (Pažitka and Wójcik 2017). On the other side of the Atlantic, the changing geography of US investment banking after the financial crisis is discussed; this highlights a shrinking industry, its spatial dispersion through offshoring and nearshoring, and the persistence of gender imbalances in the workforce (Wójcik and Cojoianu 2017). These findings are confirmed at the global level, where an overall contraction and dispersion of investment banking is detected (Wójcik et al. 2017). Development-focused works on finance also include the exploration of new trends, such as the evolution of philanthropy from grant-making towards a profit-orientated investment process (Stolz and Lai 2018), the role of stock exchanges in Africa (Klagge and Zademach 2018) and the absorption of microfinance in global circuits of capital (Mader 2018; Roy 2010)

The scope of this work is also revealed in recent analyses of governments and regulations which underline connections with the semi-periphery or emerging new centers. Sokol (2017) highlights the relationship between financialization and uneven development by discussing the financial links between core and peripheral areas in Europe. Karwowski and CenturionVicencio's (2018) work on the changing relations between states and financial markets is in part financed by a Brazilian federal agency. Alessandrini et al. $(2008,2009)$ show the impact of regulation - and technological change - on the spatial distribution of finance, characterized by the twin processes of institutional consolidation and geographical diffusion of banking services. Policy-focused research conducted in China shows that 
agglomeration economies and urban planning are crucial in the emergence of Beijing's financial center (Pan et al. 2018).

\section{TOWARDS SEMI-PERIPHERY FOCUSED FINANCIAL GEOGRAPHIES: A POLITICAL INTERPRETATION}

Building on the intuition that the state has a special role in the financial geographies of the semi-periphery, we focus on political geographical approaches for two main reasons. First and foremost, despite increasing attention to theoretical perspectives on the dynamics of state and firm production networks (Gereffi 2014; Neilson et al. 2014; Pickles et al. 2016), most scholarship resists engagement with the claims made by political geographers about structural changes in state power, organization and territoriality. Therefore, while there are rich analyses showing how regulators shape value chains and production networks, there is only limited focus on how changes in economic actors reshape various organizations within the state. Incidentally, until very recently political geography has been prone to a bias; even though several studies under the rubric of geo-economics acknowledge the role of markets in larger political decisions (Cowen and Smith 2009), they remain vague on how firm-level and consumer-level decisions affect the political sphere. Such biases are partly due to subject-matter differentiation: the focus of economic geography is on firms as pivotal actors in the modern economy, whereas political geography prioritizes organizations involved in politics (Müller 2015, p. 305). Subject-matter differentiation thus obscures analyses on the political role of economic actors in shaping and reshaping the political geographies of the nation state (Agnew 2010; Jessop 2001). By investigating the shared influences on broadly conceived (geo)political processes and the financial system (Grandi and Parenti 2019), we seek to uncover the geospatial and organizational features that have fallen through the disciplinary crevices between political and economic geography (Sellar et al. 2018).

The second reason to explore the links between political and financial geographies is because the role of the financial sector as an intermediary with transformative potential - is only diminutively understood. Thus far, economic geography research on intermediaries has focused on location consultants and investment promotion agencies (Phelps and Wood 2006, 2018); in this book we present cases in which financial institutions play an important role in shaping firms' location alongside consultants (Chapter 6 ), while themselves being shaped by the politics of regulation and decision making (Chapters 2, 7, 8, 9 and 10). This intermediary role relates to 
the reflexivity of the financial system, which responds to its own internal logic of profit as well as to external pressures from regulators, firms and systemic crises (Chapters 8, 9, 10 and 11 in this book).

There is currently an emergent thread of research on the nexus between governments, banks and the locational choices of firms. Many Italian scholars are aware of the governmental mechanisms of coordination, starting from strategic directions issued by the government, to their implementation from various ministries, and the work of public agencies in disbursing financial support and guarantees to banks and firms for export and internationalization (Vergara Caffarelli and Veronese 2018, p. 213). Within this system, banks remain independent private actors but the availability of government funds impels bank lending for internationalization projects, which are a government priority. This is a very different model from, for example, the tight state control of finance exercised by China and the various degrees of political control of finance in East Asian developmental states (Harvey 2007; Ufen 2015). Differences notwithstanding, these findings suggest caution in extending assumptions valid in and around the financial cores to the semi-periphery. In particular, many of the processes described by core-driven financial geographers pertain to a privately owned financial sector which allocates and reallocates resources - sometimes from state control at the expense of democratic processes given a profit-seeking logic. The alternative we propose is a semi-peripheral view in which non-financial actors - namely, but not exclusively, the state - affect the resources and the opportunities available to finance and, by extension, firms. This perspective sees the profit-driven process of allocating financial resources to firms and consumers less as the result of a simple calculation on return of investment. Instead, it comes across as a negotiation between various interests: that is, a political process. Herein is the rationale to interpret finance with a political-geographical lens.

\section{GEOFINANCE/BANKING AS A CONCEPTUAL FRAMEWORK LINKING POLITICAL GEOGRAPHY AND FINANCE}

As a field, political geography has developed a multiplicity of approaches since its emergence in the nineteenth century (Jones 2016). Mid-twentiethcentury positivist approaches viewed it as the study of politically bounded territorial units (Alexander 1963), and later embraced all political processes. This type of approach is distinct from political science because of the application of quantitative spatial analysis (Burnett et al. 1981). Later, structuralist and post-structuralist approaches focused on key concepts 
such as territory and the state (Cox 2002, 2003). More recently, a new political geography (Jones 2016) has opened up the field to interdisciplinary contributions, merging the political and the geographical. The former may be conceptualized as a 'triangle' including power, politics and policy, and the latter conceptualized as a 'triangle' of space, place and territory (Jones 2016, p. 2). Political geography research thus involves some, but not necessarily all, permutations of these six concepts.

Within these permutations, we are particularly interested in the relationships between policy, politics and territory. These relationships - a fixture in the discussion over the nature of the state - are treated by geographers either as static territorial frames, or as dynamic, multi-scalar and networked social processes (Jessop 2007; Moisio 2018; Moisio and Paasi 2013b). Works on state theory include the strategic relational understanding of the state (Jessop 2001). These emphasize the reciprocal influence exerted across capitalist state institutions and social action; certain institutional structures 'may privilege some actors, some identities, some strategies' that actors need to deploy to achieve their goals (Jessop 2001, p. 1220). In turn, the strategic actions of these actors shape how institutions evolve. There is thus a dialectic tension between the territorial and networked views of the state, showing that state power is the result of the interaction between territorially framed institutions and the social forces operating within and around these institutions. In the editorial of a special issue for the journal Geopolitics, Moisio and Paasi (2013a) suggest a rethink of the contrast between territorial and relational government practices. That is, states use both traditional territorial jurisdictions and relational networks in different contexts to further their resources and their reach. The fourth issue of 2010 in the same journal presents a round-table discussion of John Agnew's concept of the territorial trap (Reid-Henry 2010). This concept draws attention to the assumptions of conventional territoriality, in which state organizations and societies are neatly contained within national boundaries. The special issue advances the concept by exploring the history of the territorial state, considering forms of power other than sovereignty and rethinking the relationships among power, space and political systems (Elden 2010). Jonas (2012) builds on this to suggest that it is possible to transcend the distinction between territorial and relational by drawing on the constantly reassembled, bounded and unbounded factors that shape territory and territorial politics.

Most recently, cross-disciplinary literature discusses the role of economic actors - including, but not limited to, firms and their value chains - in the assembly and reassembly of territories and politics. Sellar's (2019; Sellar et al. 2018) argument that transnational firms and expatriate entrepreneurs act as political actors and contribute to the network-like transformation of state bureaucracies is relevant here. Building on Çalışkan and Callon 
(2009), Moisio (2018, p. 1) presents the notion of economization, understood as 'the material processes of knowledge-intensive capitalism ... and the processes whereby this form of capitalism is constructed discursively'. Moisio's key claim is that economization includes a key geopolitical dimension, constituted by both the territorial power of states and the imagery of hubs, networks and flows that permeates the late capitalist economy. Economization is able to connect firms and political communities (Moisio 2018, p. 16) and account for the reshuffling of territoriality (Moisio 2018, p. 19). Developing Moisio's point, we argue that finance and its geographies are an underexplored and crucial factor linking the evolving (bounded and relational) territorialities of the nation state with firms and citizens.

To bring together political and financial geographies is to emphasize that states and regulations are crucial in shaping the financial sector (Karwowski and Centurion-Vicencio 2018; Pan et al. 2018). In addition, the sector itself teems with a variety of organizations operating at multiple scales (Dörry 2018; Stolz and Lai 2018). Moreover, these organizations are rapidly evolving as they respond to the spatiality of finance and the state (Wójcik and Cojoianu 2017; Wójcik et al. 2017; Bassens et al. 2017). Building on these findings, we propose the notion of geofinance/banking as a way to tie together the contributions in this book while also highlighting the political-geographical role of finance; the various public and private aspects of banking that shape territorial politics, and vice versa. Figure 1.1 is a visual representation of the concept of geofinance/banking.

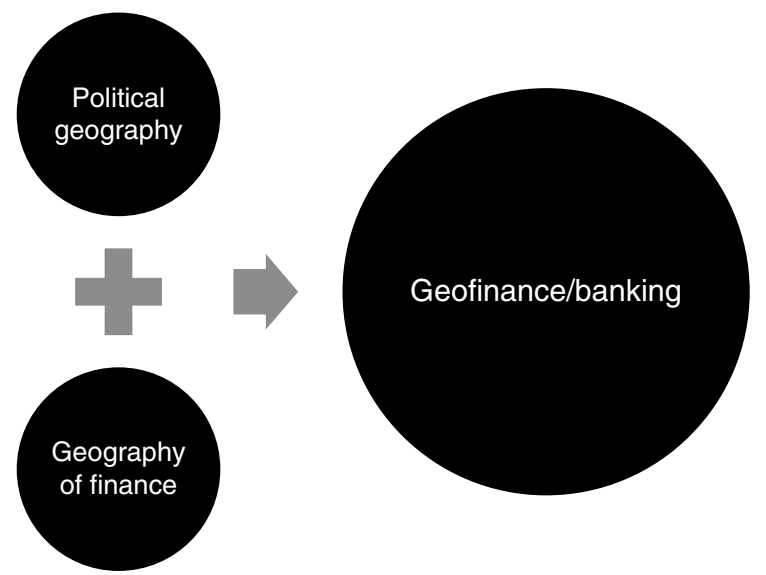

Source: Figure by Silvia Grandi, 2018.

Figure 1.1 Geofinancelbanking 
In our view, geofinance/banking refers to a complex and multi-scalar system which includes physical infrastructure and social interactions, in person as well as through digital media. Actors in the system represent a wide range of agents. These include: international financial institutions (IFIs) such as the World Bank and the European Investment Bank; large financial players including pension funds, sovereign wealth funds and stock exchanges; state-owned banks and insurers; private insurance companies and other financial service providers; and international commercial banks, offshore banks and smaller-scale financial institutions operating at the local level, including local and cooperative banks. More recently, new actors have emerged and complement these institutions and their practices: these include fintech, Islamic finance, frontier finance, crowd funding and microfinance. The term banking synthesizes the main actors, processes and fluxes of the geographies of finance. Geofinance/banking thus shapes, and is shaped by, global forces exerted simultaneously at the international, national and local scales. Particularly at the national and sub-national levels, material and immaterial landscapes of state-owned organizations, as well as private firms, which encompass large multinational corporations (MNCs) and small and medium-sized enterprises (SMEs) are shaped by, and are shaping, geofinance/banking.

Our conceptualization, which builds on Jones (2016), is thus: financial political geography focuses on the relationships among two or more of nine entities, which are either political (power, politics and policy), geographical (space, place and territory) or financial (flows, firms and institutions). While power, politics and policy with space, place and territory represent political geography, geofinance/banking adds a further triangle consisting of financial flows - labelled flows in Figure 1.2 for the sake of simplicity and which refer to the flows and management of money and other financial tools - and institutions (banks, IFIs and other actors) and client (firms and consumers). The polygon in Figure 1.2 resulting from the merger of the three triangles shows the possible influences between political and economic geographies, as mediated by finance.

The relationships shown in Figure 1.2 rest upon the semi-periphery centered assumptions discussed above; that the state influences domestic finance, which in turn shapes resources available to firms and people, while at the same time importing and adapting models from the core. We understand these relationships as a set of mutually interdependent processes of adaptation, synergies and incentives as well as threats. Thus, the permutations of geofinance/banking represent the possible links between (1) the policies of territorial states in the financial semi-periphery, (2) the interactions between these policies and globalizing processes originating in the financial core, and (3) the resulting impact on financial flows 


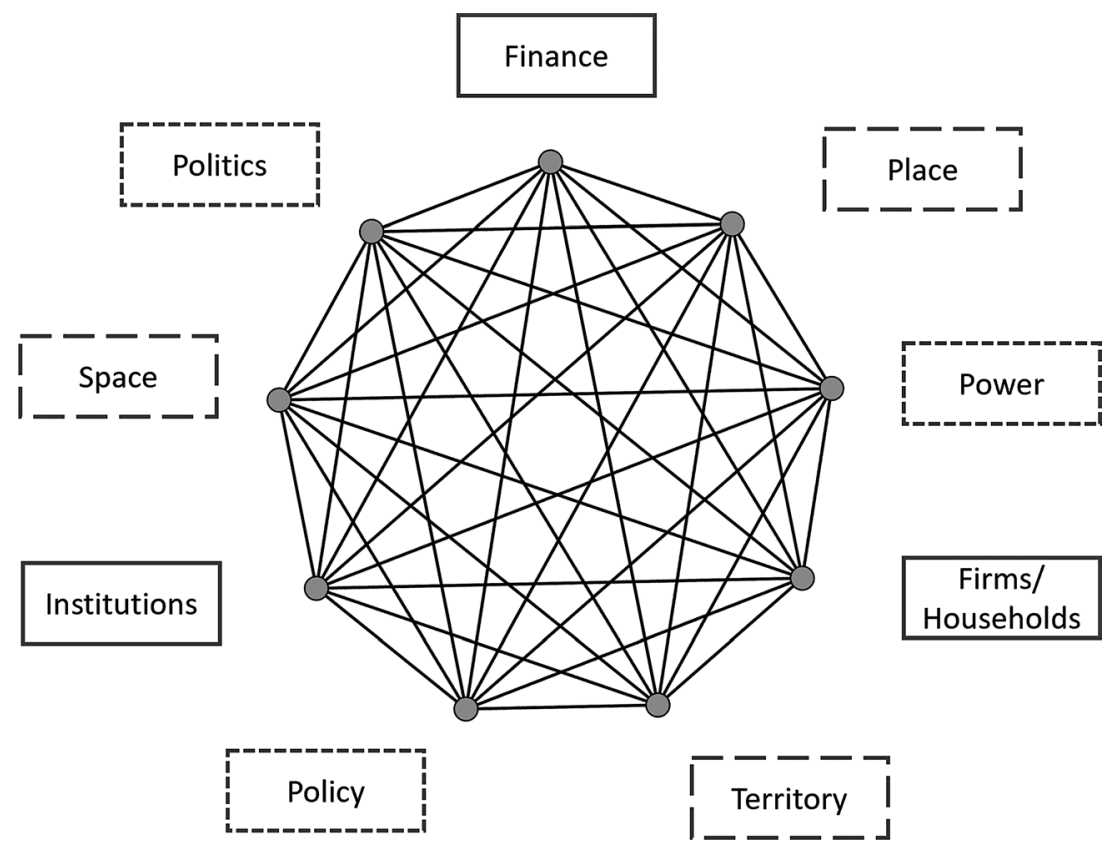

Source: Figure by Silvia Grandi, 2018.

Figure 1.2 The relational conceptualization among new political geography entities and those of geofinancelbanking

and practices affecting specific national and local economies in the semi-periphery.

Findings from each chapter flesh out our initial hypothesis of a relationship between constantly reassembled territorial politics and policies, finance, firms and people. The authors depict a rapidly evolving regulatory system, which simultaneously reacts to and constitutes a globalizing political economy. Contributions by Silvia Grandi, Gianfranco Battisti and Umberto Rosati (Chapters 2-4) set the stage by observing how a global system of financial governance, whose complex boundaries encompass both official finance and shadow banking, arises from the need to regulate the economy beyond the spatialities of the nation state; thus, the governance of finance is consistent with relational governmental practices. Contributions by Elena Stavrova and by Guanie Lim and Thong Tien Nguyen (Chapters 8 and 9) show how global pressures to implement neoliberal reforms are mediated and domesticated by national regulation of the financial system in Bulgaria and Vietnam, respectively. The influence 
of national governments is also addressed in Chapter 7 by Ageeva and Mishura, which examines the financial sector in Russia and its predilection for state-owned and Moscow-based banks, at the expense of independent regional financial institutions. Y1lmaz and Percoco (Chapters 10 and 11) offer a different take when they show how national and sub-national banking systems have responded to the challenges presented by financial crises with the acquiescence of national regulators. In turn, banks and other actors in the financial sector shape the opportunities available to firms and the public, creating support networks for internationalizing firms (Sellar, in Chapter 6), as well as patterns of inclusion/exclusion defining financial citizenship (Jafri, in Chapter 12).

\section{THE QUESTION OF INNOVATION}

Responding to the call for chapters on geofinance/banking, contributors chose to highlight some issues more than others. The most glaring absence is that none of the authors is especially concerned with technology or innovation. This might be surprising, given how much emphasis contemporary financial geography places on innovation, both relating to technology and organization (Bassens et al. 2017; Clark and Wójcik 2007; Stolz and Lai 2018). More broadly, much of economic geography's drive to understand regional economies, clusters and networks of the past 30 years has been driven by an interest in innovation (Breschi and Lenzi 2014; Cooke et al. 2004; Fromhold-Eisebith and Eisebith 2005; Saxenian 1994; Storper 1997). Even from a geopolitics standpoint, the main driver behind Moisio's discussion of economization is to enhance analyses of the knowledge-based economy; itself an ambiguous term that pertains to, among other things, high-technology, innovation-driven capitalism (Moisio 2018). Several contributors do comment on the transfer of innovation and fintech from the core financial regions. Other than the personal research interests of the contributors, limited engagement here is consistent with the classical work of Wallerstein (1974) in which innovation - in the form of capitalism and industrialism - allowed the core regions to emerge in the first place, and in which the semi-periphery either declines or seeks to join this core through the adoption of innovations generated by the main global financial centers.

While the old model of transmission of innovation from the core is now challenged by the emergence of reverse innovation technologies with potentially no boundaries (Govindarajan and Trimble 2012), there is still space for the transfer and adaptation of core-driven models. For example, in this collection Chapter 8 by Elena Stavrova configures the historical evolution of Bulgarian banking as a 'path to normality' from state socialism 
to a European model driven by transfers of technology and practices by foreign investors. Fabio Betioli Contel makes comparable arguments about Brazil in Chapter 5, and Svetlana Ageeva and Anna Mishura take a similar approach for Russia in Chapter 7. Thus, rather than an omission, the lack of focus on innovation by our contributors suggests a need for more nuance on the relative importance of innovation in non-core based research.

It is not that Bulgaria - or Italy, or Turkey and the other cases represented here - are incapable of financial innovation; quite the opposite. Indeed, Wallerstein (1976) noticed that the attempts by the semi-peripheries to join the core may lead to revolutions and daring experimentations. Most recently, in the field of finance, formerly semi-peripheral areas in East Asia have driven innovation in fintech (Lai 2018). Rather than denying the importance of innovation, our cases note that innovation is one among many options available to actors in the semi-periphery. For example, in the particular cases discussed in the following chapters, local interests have steered public and academic discourse to an emphasis on imported models, rather than highlighting home-grown innovation. ${ }^{1}$ In turn, those models are transformed and adapted in practice, even when not in rhetoric, as shown in by Lim and Nguyen in Chapter 9 on banking reforms in Vietnam, where strictly neoliberal economic reforms were stalled and tweaked during implementation.

\section{REFLECTIONS ON THE BROADER ROLE OF FINANCIAL SEMI-PERIPHERIES}

Problematizing the role of innovation leads to bigger questions about the role of the semi-periphery in the global financial system. On the one hand, the empirical material discussed in the following chapters does not lend itself to large-scale generalizations about the influence of the semiperiphery on the core and the periphery. On the other hand, our own conceptual tool of geofinance/banking is designed to investigate multi-scalar trends owing to the entanglement between finance and the state, rather than a macro-level picture of semi-peripheries as buffer and the expansion zone for peripheralizing and core-forming processes (Arrighi and Drangel 1986). In summary, this work seeks to be a starting point for a discussion about two gaps in financial geography by (1) introducing the perspective of the semi-peripheries and (2) calling for a closer attention to the politics and geopolitics of finance. While much more has been written on politics and finance - for example, Hardie (2012) on the constraints of government borrowing in emerging markets, or Krijnen et al. (2017) for analyses of 
finance in the world-city tradition - we as editors resist over-theorizing by keeping the conceptual contribution focused on geography.

While the theoretical contribution of the whole book is targeted and specific, the empirical content is wide ranging: the chapters connect with a variety of disciplines and engage with two trends on the broader role of the semi-periphery of global finance. First, some chapters point to vulnerabilities and dependence on the core; for example, bank lending practices in Turkey, the vulnerability of Italian regional banks to crises and the reactive nature of banking policies in Bulgaria. Second, there are clear signs of pushbacks in which the orchestration of finance by the state mediates the pressures from the core: this is seen in Chapters 7 and 9 on Russia and Vietnam, respectively. The book seeks to view the semi-periphery as a place of experimentation for the politics of finance - albeit perhaps less daring in financial innovation than the periphery owing to the path dependency of already established 'brick and mortar' banking - but also presenting a variety of entanglements between states and markets that are not immediately apparent.

The three parts and the chapters of this book together highlight the need for focused research on the middle ground between financial cores and places at the margins of finance: we refer to these as semi-peripheral financial areas. Our approach thus complements perspectives on core financial centers and articulates the presence of a geofinance/banking landscape which encompasses meso-level as well as micro-level structures. Moreover, by juxtaposing the fixtures of political science - politics, policy and power - with those from political geography fixtures - such as space, place and territory - and then enriching them with fixtures from finance - such as flows, banking institutions and firms/households - we arrive at a conceptual and analytical framework for geofinance/banking.

\section{NOTE}

1. Another Bulgarian example of manipulating Western discourses on innovation is reported by Sellar et al. (2011), showing how European Union innovation policies conceived in Brussels with the explicit aim of competing with Silicon Valley over cutting-edge innovation were reinterpreted in Bulgaria as a tool to acquire resources to revitalize old industrial centers.

\section{REFERENCES}

Agnew, J. (2010), 'Still trapped in territory?', Geopolitics, 15 (4), 779-84.

Alessandrini, P., Presbitero, A.F. and Zazzaro, A. (2008), 'Banks, distances and firms' financing constraints', Review of Finance, 13 (2), 261-307. 
Alessandrini, P., Presbitero, A.F. and Zazzaro, A. (2009), 'Geographical organization of banking systems and innovation diffusion', in P. Alessandrini, P. Fratianni and A. Zazzaro (eds), The Changing Geography of Banking and Finance, New York: Springer, pp. 75-108.

Alexander, L.M. (1963), World Political Patterns, Chicago, IL: Rand McNally.

Arrighi, G. and Drangel, J. (1986), 'The stratification of the world-economy: an exploration of the semiperipheral zone', Review (Fernand Braudel Center), 10 (1), 9-74.

Bassens, D., Hendrikse, R. and Van Meeteren, M. (2017), 'The Appleization of finance - reflections on the Fintech (R)evolution', FinGeo Working Paper No. 2, March, Global Network on Financial Geography, Oxford University.

Breschi, S. and Lenzi, C. (2014), 'The role of external linkages and gatekeepers for the renewal and expansion of US cities, knowledge base, 1990-2004', Regional Studies, 49 (5), 782-97.

Burnett, A.D., Taylor, P.J. and Taylor, P.J. (1981), Political Studies from Spatial Perspectives: Anglo-American Essays on Political Geography, New York: John Wiley \& Sons.

Byrne, M. and Norris, M. (2017), 'Financial circuits: cyclicality, leakiness and social housing finance in Ireland and Denmark', FinGeo Working Paper No. 5, July, Global Network on Financial Geography, Oxford University.

Çalışkan, K. and Callon, M. (2009), 'Economization, part 1: shifting attention from the economy towards processes of economization', Economy and Society, 38 (3), 369-98.

Cassis, Y. and Wójcik, D. (2018), International Financial Centres after the Global Financial Crisis and Brexit, Oxford: Oxford University Press.

Clark, G.L. and Wójcik, D. (2007), The Geography of Finance: Corporate Governance in the Global Marketplace, Oxford: Oxford University Press.

Cooke, P.N., Heidenreich, M. and Braczyk, H.-J. (2004), Regional Innovation Systems: The Role of Governance in a Globalized World, Hove: Psychology Press.

Cowen, D. and Smith, N. (2009), 'After geopolitics? From the geopolitical social to geoeconomics', Antipode, 41 (1), 22-48.

Cox, K.R. (2002), Political Geography: Territory, State and Society, Cambridge, MA: Blackwell.

Cox, K.R. (2003), 'Political geography and the territorial', Political Geography, 22 (6), 607-10.

Dixon, A.D. and Monk, A. (2014), 'Frontier finance', Annals of the Association of American Geographers, 104 (4), 852-68.

Dörry, S. (2018), 'Creating institutional power in financialised economies: the firmprofession nexus of advanced business services', FinGeo Working Paper No. 12, March, Global Network on Financial Geography, Oxford University.

Elden, S. (2010), 'Thinking territory historically', Geopolitics, 15 (4), 757-61.

Fernandez, R. (2017), 'Stylized facts from housing and finance: how do they relate across space and time?', FinGeo Working Paper No. 1, March, Global Network on Financial Geography, Oxford University.

FinGeo (2018), 'Research themes', accessed 16 July 219 at http://www.fingeo.net/ research-themes/.

Fromhold-Eisebith, M. and Eisebith, G. (2005), 'How to institutionalize innovative clusters? Comparing explicit top-down and implicit bottom-up approaches', Research Policy, 34 (8), 1250-68. 
Gereffi, G. (2014), 'Global value chains in a post-Washington consensus world', Review of International Political Economy, 21 (1), 9-37.

Govindarajan, V. and Trimble, C. (2012), Reverse Innovation: Create far from Home, Win Everywhere, Brighton, MA: Harvard Business Press.

Grandi, S. (2018), Viaggio tra le concezioni dello sviluppo. Teorie ed evoluzioni (A Journey among Different Understandings of Development. Theories and Evolution), Bologna: La Mandragora.

Grandi, S. and Parenti, F.M. (2019), 'Geography matters in finance? Frontiers, polarizations, alternatives and geopolitical elements for financial analysis', in S. Boubaker and D.K. Khuong Nguyen (eds), Handbook of Global Financial Markets: Transformations, Dependence, and Risk Spillovers, Singapore: World Scientific, pp. 767-88.

Hardie, I. (2012), Financialization and Government Borrowing Capacity in Emerging Markets, Basingstoke: Palgrave Macmillan.

Harvey, D. (2007), A Brief History of Neoliberalism, Oxford and New York: Oxford University Press.

Jessop, B. (2001), 'Institutional re(turns) and the strategic-relational approach', Environment and Planning A, 33 (7), 1213-36.

Jessop, B. (2007), State Power, Cambridge: Polity.

Jonas, A.E.G. (2012), 'Region and place: regionalism in question', Progress in Human Geography, 36 (2), 263-72.

Jones, M. (2016), 'Polymorphic political geographies', Territory, Politics, Governance, 4 (1), 1-7.

Karwowski, E. and Centurion-Vicencio, M. (2018), 'Financialising the state: recent developments in fiscal and monetary policy,' FinGeo Working Paper No. 11, February, Global Network on Financial Geography, Oxford University.

Klagge, B. and Zademach, H.-M. (2018), 'International capital flows, stock markets, and uneven development: the case of sub-Saharan Africa and the Sustainable Stock Exchanges Initiative (SSEI)', Zeitschrift Für Wirtschaftsgeographie, 62 (2), 92-107.

Krijnen, M., Bassens, D. and Van Meeteren, M. (2017), 'Manning circuits of value: Lebanese professionals and expatriate world-city formation in Beirut', Environment and Planning A, 49 (12), 2878-96.

Lai, K.P.Y. (2018), 'Singapore: connecting Asian markets with global finance', in Y. Cassis and D. Wójcik (eds), International Financial Centres after the Global Financial Crisis and Brexit, Oxford: Oxford University Press, pp. 154-81.

Mader, P. (2018), 'Contesting financial inclusion', Development and Change, 49 (2), 461-83.

Moisio, S. (2018), Geopolitics of the Knowledge-Based Economy, London: Routledge.

Moisio, S. and Paasi, A. (2013a), 'Beyond state-centricity: geopolitics of changing state spaces', Geopolitics, 18 (2), 255-66.

Moisio, S. and Paasi, A. (2013b), 'From geopolitical to geoeconomic? The changing political rationalities of state space', Geopolitics, 18 (2), 267-83.

Müller, M. (2015), 'Geography of organization', in J. Wright (ed.), International Encyclopedia of the Social \& Behavioral Sciences, 2nd edn, Amsterdam: Elsevier, pp.301-6.

Neilson, J., Pritchard, B. and Wai-chung Yeung, H. (2014), 'Global value chains and global production networks in the changing international political economy: an introduction', Review of International Political Economy, 21 (1), 1-8. 
Pan, F., Hall, S. and Zhang, H. (2018), 'The geographies of financial activities within an emerging international financial center: the case of Beijing', FinGeo Working Paper No. 10, January, Global Network on Financial Geography, Oxford University.

Parenti, F. and Rosati, U. (2018), Geofinance and Geopolitics, Milan: Egea.

Pažitka, V. and Wójcik, D. (2017), 'Cluster dynamics of financial centres in the United Kingdom: do connected firms grow faster?', FinGeo Working Paper No. 4, July, Global Network on Financial Geography, Oxford University.

Phelps, N. and Wood, A. (2006), 'Lost in translation? Local interests, global actors and inward investment regimes', Journal of Economic Geography, 6 (4), 493-515.

Phelps, N. and Wood, A. (2018), 'The business of location: site selection consultants and the mobilisation of knowledge in the location decision', Journal of Economic Geography, 18 (5), 1023-44.

Pickles, J., Smith, A., Begg, R., Bucek, M., Roukova, P. and Rudolf, P. (2016), Articulations of Capital: Global Production Networks and Regional Transformations, New York: John Wiley \& Sons.

Reid-Henry, S. (2010), 'The territorial trap fifteen years on', Geopolitics, 15 (4), $752-56$.

Roy, A. (2010), Poverty Capital: Microfinance and the Making of Development, New York: Routledge.

Saxenian, A. (1994), Regional Advantage: Culture and Competition in Silicon Valley and Route 128, Cambridge, MA: Harvard University Press.

Sellar, C. (2019), 'Transnationalizing bureaucracies through investment promotion: the case of Informest', Environment and Planning C: Politics and Space, 37 (3), 461-79.

Sellar, C., Emilova, M., Petkova-Tancheva, C.D. and McNeil, K. (2011), 'Cluster policies in Bulgaria: European integration, postsocialist dynamics and local level initiatives', International Journal of Urban and Regional Research, 35 (2), 358-78.

Sellar, C., Lan, T. and Poli, U. (2018), 'The geoeconomics/politics of Italy's investment promotion community', Geopolitics, 23 (3), 690-717.

Sokol, M. (2017), 'Financialisation, financial chains and uneven geographical development: towards a research agenda', Research in International Business and Finance, 39, 678-85.

Stolz, D. and Lai, K.P.Y. (2018), 'Philanthro-capitalism, social enterprises and global development', FinGeo Working Paper No. 13, March, Global Network on Financial Geography, Oxford University.

Storper, M. (1997), The Regional World: Territorial Development in a Global Economy, New York: Guilford Press.

Ufen, A. (2015), 'Laissez-faire versus strict control of political finance: hegemonic parties and developmental states in Malaysia and Singapore', Critical Asian Studies, 47 (4), 564-86.

Vergara Caffarelli, F. and Veronese, G. (2018), 'Costs of Italian economic diplomacy: a comparative perspective', in P. Van Bergeijk and S. Moons (eds), Research Handbook on Economic Diplomacy Bilateral Relations in a Context of Geopolitical Change, Cheltenham, UK and Northampton, MA, USA: Edgar Elgar, pp. 204-19.

Wallerstein, I. (1974), The Modern World-System: Capitalist Agriculture and the Origins of the European World-Economy in the Sixteenth Century, New York: Academic Press.

Wallerstein, I. (1976), 'Semi-peripheral countries and the contemporary world crisis', Theory and Society, 3 (4), 461-83. 
Wójcik, D. (2013), 'The dark side of NY-LON: financial centres and the global financial crisis', Urban Studies, 50 (13), pp. 2736-52.

Wójcik, D. and Cojoianu, T. (2017), 'Unfinished business: change in the US securities industry since 2008', Fin Geo Working Paper No. 9, October, Global Network on Financial Geography, Oxford University.

Wójcik, D., Knight, E., O’Neill, P. and Pažitka, V. (2017), 'Investment banking since 2008: geography of shrinkage and shift', FinGeo Working Paper No. 3, Global Network on Financial Geography, Oxford University. 